IZA DP No. 8932

Gender Differences in the Effect of Residential Segregation on Workplace Segregation among Newly Arrived Immigrants

Tiit Tammaru

Magnus Strömgren

Maarten van Ham

Alexander Danzer

March 2015 


\title{
Gender Differences in the Effect of Residential Segregation on Workplace Segregation among Newly Arrived Immigrants
}

\author{
Tiit Tammaru \\ University of Tartu \\ Magnus Strömgren \\ Umeå University \\ Maarten van Ham \\ Delft University of Technology and IZA
}

Alexander Danzer

University of Munich and IZA

Discussion Paper No. 8932

March 2015

\author{
IZA \\ P.O. Box 7240 \\ 53072 Bonn \\ Germany \\ Phone: +49-228-3894-0 \\ Fax: +49-228-3894-180 \\ E-mail: iza@iza.org
}

Any opinions expressed here are those of the author(s) and not those of IZA. Research published in this series may include views on policy, but the institute itself takes no institutional policy positions. The IZA research network is committed to the IZA Guiding Principles of Research Integrity.

The Institute for the Study of Labor (IZA) in Bonn is a local and virtual international research center and a place of communication between science, politics and business. IZA is an independent nonprofit organization supported by Deutsche Post Foundation. The center is associated with the University of Bonn and offers a stimulating research environment through its international network, workshops and conferences, data service, project support, research visits and doctoral program. IZA engages in (i) original and internationally competitive research in all fields of labor economics, (ii) development of policy concepts, and (iii) dissemination of research results and concepts to the interested public.

IZA Discussion Papers often represent preliminary work and are circulated to encourage discussion. Citation of such a paper should account for its provisional character. A revised version may be available directly from the author. 


\title{
ABSTRACT \\ Gender Differences in the Effect of Residential Segregation on Workplace Segregation among Newly Arrived Immigrants*
}

\begin{abstract}
Contemporary cities are becoming more and more diverse in population as a result of immigration. Research also shows that within cities residential neighborhoods are becoming ethnically more diverse, but that residential segregation has remained persistently high. High levels of segregation are often seen as negative, preventing integration of immigrants in their host society and having a negative impact on people's lives. Segregation research often focuses on residential neighborhoods, but ignores the fact that a lot of interaction also takes place in other spheres of life, such as the workplace. This paper examines the role of residential segregation in workplace segregation among recently arrived immigrants. By using unique longitudinal register data from Sweden, we show that the role of residential segregation in workplace segregation differs in an important way for immigrant men and immigrant women.
\end{abstract}

JEL Classification: J15, J61, R23

Keywords: immigrants, residential segregation, workplace segregation, longitudinal analysis, Sweden

Corresponding author:

Tiit Tammaru

Department of Geography

University of Tartu

Vanemuise 46

Tartu 51014

Estonia

E-mail: tiit.tammaru@ut.ee

\footnotetext{
* The research leading to these results has received funding from the European Research Council under the European Union's Seventh Framework Programme (FP/2007-2013) / ERC Grant Agreement n. 615159 (ERC Consolidator Grant DEPRIVEDHOODS, Socio-spatial inequality, deprived neighbourhoods, and neighbourhood effects) and from the Marie Curie programme under the European Union's Seventh Framework Programme (FP/2007-2013) / Career Integration Grant n. PCIG10-GA-2011-303728 (CIG Grant NBHCHOICE, Neighbourhood choice, neighbourhood sorting, and neighbourhood effects).
} 


\section{Introduction}

Research interest in ethnic segregation is increasingly expanding beyond residential neighborhoods (Strömgren et al. 2014; van Kempen and Wissink 2014). The place where one lives is not sufficient in understanding people's lives, including immigrant integration pathways in their host societies (Kwan 2013; Marcinczak et al. 2015; Wong and Shaw 2011). For working people it is also important to consider workplaces, since these are important arenas for social interaction and a crucial source of livelihood (Baron and Bielby 1980; Marcinczak et al. 2015; Tomaskovic-Devey et al. 2006). As a lot of people tend to spend more time interacting with co-workers than with their neighbors, it is important to get more insight in whether high levels of residential segregation of immigrants are reproduced in high levels of workplace segregation. Such insight is crucial for understanding the integration pathways of the newly arrived immigrants in their host countries. Recent research on segregation has therefore started to take an interest in the workplace context of immigrants, as well as in comparing levels of residential and workplace segregation (Bygren 2013; Ellis et al. 2004; Hou 2009; Marcinczak et al. 2015; Strömgren et al. 2014). Less is known on how the two are related to each other, i.e. whether immigrants living in ethnic enclaves also tend to work in ethnically segregated workplaces. Although the literature suggests important gender differences (Parks 2004), even less is known about how the relationship between residential neighborhoods and workplaces differs between men and women.

The aim of this paper is to get more insight in whether residential segregation contributes to workplace segregation among newly arrived immigrants ${ }^{1}$ in Sweden. The growth of the immigrant population has been especially rapid in Europe compared to other main destinations of immigration across the globe over the last decades (Castles et al. 2013), making European cities increasingly diverse (Syrett and Sepulveda 2012). An important destinations for migrants in Europe is Sweden, a country that has traditionally been very open to refugees from the Global South. The Migrant Policy Index MIPEX (2015) ranks Sweden as the number one country in the world when it comes to institutional setup and policies aimed at integration of immigrants and creating equal opportunities for all. With regard to labor market policies, Sweden receives the highest possible score, and this makes Sweden an interesting country for analyzing (changes in) both levels of residential and workplace segregation.

This paper contributes to the literature in three important ways. First, it brings forward the ongoing discussions on segregation as a multidimensional process (Marcinczak et al. 2015; Tammaru et al. 2015) by providing a better understanding of the association between residential and workplace segregation among newly arrived immigrants. We take into account the ethnic composition of the household in studying the role of residential segregation in workplace segregation since for recently arrived immigrants, mixed ethnic unions with natives might lead to different neighborhood and workplace outcomes than co-ethnic unions (Ellis et al. 2012; Feng et al 2013; Strömgren et al. 2014). Second, we use longitudinal data, while most existing studies on segregation use cross-sectional data. The use of longitudinal data allows us to take into account that the sorting of immigrants into workplaces, residential neighborhoods and partnerships is not random; the processes behind settling in an ethnic residential enclave and finding a job in an ethnic niche sector could be

\footnotetext{
${ }^{1}$ We focus on immigrants from the Global South: from Africa, Asia (with the exception of Japan), Middle East and South America.
} 
guided by the very same underlying reasons that are difficult to capture with cross-sectional data. Third, we study workplace segregation of immigrants separately for men and women. While previous studies have emphasized the importance of gender in getting a job or wages, a gender-specific assessment of workplace segregation has found less attention (but see Hanson and Pratt 1991; Parks 2004).

\section{The hypothesis: the effect of residential segregation on workplace segregation is stronger for immigrant men compared to immigrant women}

The relationships between places of residence and places of work is one of the core interest in urban geography (Alonso 1964; Ellis et al., 2004; Hanson and Pratt 1988; Strömgren et al. 2014; van Ham et al. 2001). Newly arrived immigrants settle somewhere from the very first day of arrival, but it takes time to establish themselves on the labor market (Hedberg and Tammaru 2013). This way, the place of residence becomes an important anchor of people's daily activity space (Schnell and Yoav 2001; Silm and Ahas 2014) and it largely determines the job search area of newly arrived immigrants. Immigrants often settle in ethnic enclaves upon arrival since for many of them, migration is a network-based event where co-ethnics help with getting shelter, and provide a familiar setting in ethnic enclaves and niche jobs (Alba et al. 1995; Logan et al. 2002).

When it comes to labor market outcomes, settling in ethnic enclaves is not necessarily beneficial for immigrants. Hedberg and Tammaru (2013) demonstrate that those immigrants who find their first shelter in ethnic enclaves lag behind immigrants settling elsewhere in getting their first job upon arrival to Sweden. Musterd et al. (2008) focus on the wages of newly arrived immigrants and conclude that living in an ethnic residential enclave is beneficial for immigrant wages upon arrival, but that this positive effect is reversed within the first few years of living in the host country. The pioneering study by Ellis et al. (2004) on the relations between residential segregation and workplace segregation of native-born and immigrant groups in Los Angeles at the level of census tracts, found that $40 \%$ of workplace segregation is due to residential segregation. Based on cross-sectional data from Sweden, Marcinczak et al. (2015) also demonstrate that residential segregation is reproduced in workplace segregation.

Parks (2004) distinguishes two mechanisms that might explain the relationship between segregation in residential neighborhoods and workplaces: immigrant neighborhoods may be located near immigrant employment sites, and place-based social networks play a role in finding jobs:

... a delimited physical space within which ethnic networks concentrate and circulate. To the extent that ethnic employment networks are partially rooted in residential neighborhoods, we should expect to see a relationship between living in an immigrant enclave neighborhood and working in an immigrant-niche job (p. 593).

Relying on evidence from the U.S., Hellerstein et al. (2008; 2011; 2014) confirm the importance of neighborhood ethnic context in explaining workplace segregation. Bound to the use of cross-sectional data, they restrict their attention to those residents who had not moved in the past years and who worked in establishments that were less than five years old, and for whom the choice of residential location necessarily preceded the decision to work at a new establishment. They found strong evidence for residence-based networks on workplace 
segregation.

The longitudinal study by Strömgren et al. (2014), using data from Sweden, demonstrates that the link between residential segregation and workplace segregation stems largely from the fact that immigrants with certain individual characteristics tend to self-select simultaneously into certain residential neighborhoods and workplaces. In other words, although residential segregation is reproduced in workplace segregation, segregation in both environments is mainly caused by the very same selection processes. They further show that the residential segregation is also partly responsible for workplace segregation; after controlling for a range of other factors they still find living in ethnic enclaves is positively associated with working in more segregated workplaces.

To shed new light on the role of residential neighborhoods in understanding workplace segregation we will study workplace segregation separately for newly arrived immigrant men and women, since the literature suggests important gender differences (Parks 2004). These differences can arise because the social networks of immigrant women tend to be smaller and more residential neighborhood-based than those of immigrant men (Moore 1990; Wang 2010). Also, immigrant women tend to work closer to home because they tend to have more household-related responsibilities compared to men (Hanson and Pratt 1992). Both factors lead us to hypothesize that living in an ethnic enclave could lead to higher levels of workplace segregation for immigrant women compared to immigrant men. To the best of our knowledge, no studies have explicitly focused on the differences in the link between residential segregation and workplace segregation of immigrant men and immigrant women. The studies closest to us have explored the link between residential segregation and niching in the labor market. For example, Parks (2004) shows, based on data from Los Angeles, that niche employment is more common among immigrant women than among immigrant men, especially if they live in enclave neighborhoods.

\section{Other aspects influencing workplace segregation}

The effect of residential segregation on workplace segregation among newly arrived immigrants is mediated by many other important factors (see Strömgren et al. 2014). Here, we focus on three of them, intermarriage with natives (partners share residential neighborhoods), city size (important for job supply) and education (which is a key worker productivity characteristic). For a newly arrived immigrant, having a native partner could help to accumulate country-specific tacit knowledge, also about the ways the labor market operates (Alba and Nee 2003; Dribe and Lundh 2008). The association between intermarriage with a native and workplace segregation is complex. For the entire immigrant population in Sweden, Strömgren et al. (2014) find that-without taking into account the selection into partnerships and workplaces - both men and women with a native partner work in workplaces with higher share of natives, i.e. in a more integrated workplaces.

Workplace segregation is an equilibrium outcome of labor demand and supply. The labor demand side hinges on the number and variety of jobs on offer, as well as on the employment strategies of firms. The number of jobs available for immigrants is strongly correlated to city size; immigrants arriving in larger cities with a more diverse labor market tend to have better opportunities to finding a job compared to immigrants arriving in smaller places (Hedberg and Tammaru 2013). However, workplaces in larger cities tend to be more segregated 
compared to workplaces in smaller cities, for reasons such as a larger size of the migrant communities and more developed ethnic niche jobs compared to medium sized and smaller cities (Strömgren et al. 2014). When it comes to employment strategies, on the one hand, employers in the host country tend to discount the education and previous country of origin work experience of recently arrived immigrants, pushing them towards less desirable jobs in the periphery of the labor market. Even a mild employer bias in the hiring process can result in substantial discrimination of immigrants on the labor market (Arrow 1973; Rydgren 2004), thus sorting immigrants and natives into the different workplaces. Higher wages in the host country compared to home country explain the willingness of immigrant workers to take low status and precarious jobs upon arrival, even when below their skill level (Arnholtz and Hansen 2012).

On the other hand, employers competing with each other could also gain from the diversity of their workers (Syrett and Sepulveda 2012); cultural diversity is often considered as one of the key success factors of organization in the increasingly globalized world. Cultural diversity in the work force may facilitate knowledge spillovers and increase knowledge necessary for innovation, and open up new export markets and pave the way to a diversified consumer base in the home country. So diversity helps to shift the focus towards the importance of learning, skills and expansion in order to survive in the local and global innovation economy (Kourtit et al. 2013). In this context, employer preferences towards natives in the hiring process could work against the competitive edge of enterprises. Furthermore, legislative developments increasingly aim to diminish discrimination and inequality on the labor market (Stjernström 2014).

The supply side crucially depends on formal skills. Education is thus an important mediating factor for workplace segregation (Strömgren et al. 2014). On the one hand, better educated individuals find jobs more efficiently and effectively. On the other hand, a higher educational attainment leads to a greater range of potential jobs. Since immigrants tend to suffer from skill depreciation and occupational downgrading upon arrival (Arnholtz and Hansen 2012), immigrants with already a low level of education will find it hard to receive job offers of decent quality. While there are theoretically good reasons to believe that high and low educated Global South immigrants will have different pathways of workplace segregation, there is little empirical evidence on this issue.

To conclude, previous research shows that immigrant residential segregation is reproduced in immigrant workplace segregation. This might mostly be a function of joint selection into residential neighborhoods and workplaces. However, the role of the residential neighborhood context itself might be important too. The effect of residential segregation on workplace segregation is likely to be gender specific, and it is mediated by many factors such as being intermarried with a native, city size and level of education. In this paper, we take a more explicit focus on gender differences in workplace segregation of newly arrived immigrants in Sweden, in order to come to a better understanding of how residential segregation affects workplace segregation.

\section{Data and Methods}

We use data from the longitudinal Swedish Population Register, which includes the whole Swedish population from 1990 onwards, and which allows researchers to follow individuals 
over time. Our research data includes all immigrants who entered Sweden from the Global South in 1990, 1995 and 2000. Such strategy allows us to take into account the fact that immigration to Sweden grew rapidly in the 1990s and, given that migration is often a network based phenomenon (Alba and Nee 2003), those immigrants who arrived in 2000 had a much higher probability to rely on co-ethnics in finding their first residence and their first job compared to those who arrived in 1990. The Swedish Population Register does not include information on race or ethnicity and, therefore, we capture the diversity of immigrants in Sweden by focusing on the country of origin of immigrants, a common strategy in countries with register data (e.g. Damm 2014). Immigrants from Global South originate from the Middle East (including North Africa), Africa, Asia, and South America. We construct a panel dataset and follow each immigrant cohort, year-by-year, up to five years after their arrival; i.e. we follow immigrants who arrived in 1990 up to 1994, immigrants who arrived in 1995 up to 1999, and immigrants who arrived in in 2000 up to 2004. Overall, our research population includes 13,279 individuals with 43,993 observations. We model the workplace segregation of immigrants by applying, first, ordinary least squares regression on our panel dataset in order to shed light on structural workplace segregation:

$$
Y_{i}=\beta_{0}+\beta_{1} \text { NeighExposure }_{i}+\beta_{2} \text { NativePartner }_{i}+X+\varepsilon_{i}
$$

We model separately workplace segregation for immigrant men and women. For immigrant $i$, the dependent variable $Y$ measures the share of native co-workers at his/her workplace establishment. Establishments are defined by exact postal address. In order to study the relationship between residential and workplace segregation, the explanatory variable of main interest is the share of native Swedes in individual i's neighborhood of residence (NeighExposure, ranging between zero and one). Following previous studies for Sweden (Tammaru et al. 2010; Åslund and Nordström-Skans 2010), we define residential neighborhoods as SAMS areas that are the smallest spatial statistical units in Sweden used for planning purposes, with an average population of about 1,000 inhabitants.

Our main hypothesis stated that for immigrant women it helps more than for men to live together with natives in their residential neighborhood to reduce workplace segregation. Since partners share their neighborhood of residence, we add a dummy indicating having a native partner (NativePartner) into our regression model. We further control for other relevant individual characteristics in our regression model (denoted with $X$ in the equation) by including immigrant region of origin, year of immigration, gender, education, age at arrival in Sweden, years since arrival, citizenship, neighborhood population size, Swedish macro regions, Swedish citizenship and industry/line of business (see Table 1 for descriptive statistics). The model includes also the error term $\varepsilon$.

\section{TABLE 1 ABOUT HERE}

Estimating model (1) does not take into account the fact that immigrant selection into residential neighborhoods and workplaces is influenced by the same underlying individual characteristics that we cannot directly measure. For example, an individual's ability or difficulties to integrate in the host society can simultaneously play a role in settling in an ethnic enclave neighborhood and in finding a job in an ethnic workplace. Such unmeasured characteristics are absorbed in the error term $\varepsilon$ in equation 1 . To overcome the problem that some unmeasured individual characteristics jointly influence workplace and residential 
segregation, we estimate also a fixed effects regression model for the change in workplace segregation:

$$
Y_{i t}=\beta_{0}+\beta_{1} \text { NeighExposure }_{i t}+\beta_{2} \text { NativePartner }_{i t}+X+\alpha_{i}+\varepsilon_{i t}
$$

This fixed effects model thus focuses on the association between the change of workplace segregation and the change of residential segregation. Those unmeasured individual characteristics that do not change over time (such as ability and willingness to integrate) are now captured by the individual fixed effect $\alpha_{i}$, and no longer bias our estimates of residential segregation on workplace segregation. Again, we run separate models for immigrant men and women since their trajectories differ on the Swedish labor market, for example when it comes to the speed of getting the first job after arrival (Hedberg and Tammaru 2013). This study is about segregation. For the sake of diversifying language in the empirical section, we use also the term workplace integration when referring to (a) the lower levels of workplace segregation of one group compared to another group, or (b) the decrease of workplace segregation of immigrants from natives over time.

\section{Gender differences in the effect of residential segregation on workplace segregation}

General changes in workplace segregation, residential segregation and intermarriage The share of immigrants in Sweden is about $15 \%$ of the total population which implies that if immigrants and natives are equally distributed across residential neighborhoods and workplace establishments, $85 \%$ of their neighbors and co-workers should be native Swedes. However, this is not the case since about $3 / 4$ of immigrants have native neighbors and $2 / 3$ have native co-workers (Table 2). This implies that that immigrants are more likely to work in ethnic niches on the labor market than to live in ethnic residential enclaves. The differences in workplace segregation and residential segregation are small between regions of origin and gender.

\section{TABLE 2 ABOUT HERE}

The results for intermarriage are different. If the probability of finding a partner would reflect the share of immigrants, the rate of intermarriage would be $15 \%$ in Sweden. Although most immigrant men and women from the various origin groups have intermarriage rates between $10 \%$ and $20 \%$, the variation is much bigger compared to residential and workplace segregation. Intermarriage of immigrant men from Middle East and Africa with natives is much more common compared to immigrant women, and intermarriage of immigrant women from Asia and South America with natives is much more common compared to immigrant men. Only 5\% of immigrant women from Middle East and as many as 32\% of immigrant women from Asia have a Swedish partner (see also Niedomysl et al. 2010). Although not directly obvious, this is important when thinking about the meaning of segregation in residential neighborhoods. A neighborhood with a high percentage of mixed ethnic unions is very different from a neighborhood with a high percentage of co-ethnic unions.

Changes in workplace and residential segregation of Global South immigrants during the first five years after arrival in Sweden are very interesting. With time, workplace integration with natives increases for both men and women from all regions of origin, the only exception being men from Africa. Residential segregation shows an opposite trend: with time, 
residential segregation increases for both men and women from all origins. This implies that a convergence of segregation takes place at those two important domains of daily life, but the portion of Global South immigrants living with native neighbors remains higher than the portion of those working together with native co-workers. Changes in intermarriage rates are the largest, with opposite trends for men and women. The share of Global South immigrant men having a native Swedish partner decreases significantly during the first five years after arrival while intermarriage increases among women from Asia and South America.

\section{The gendered role of residential segregation in workplace segregation}

We continue by investigating structural segregation by focusing on the role of residential segregation in workplace segregation, with the dependent variable being the share of natives in the workplace establishment where Global South immigrant men and women work. Ordinary least squares regression models for both men and women (Table 2, Model 1a and Model 1b) indicate that living in a neighborhood with a higher share of natives is associated with a higher share of natives in immigrants' workplaces and the results are very similar for men and women. This is an important finding since we do take into account the fact that some immigrants, especially immigrant women, are intermarried with natives, while others are not. Having a native partner itself is positively related to a higher share of natives in the workplace as well. The results also confirm findings of the descriptive analysis that the share of natives in workplace establishments increases with years since arrival.

\section{TABLE 3 ABOUT HERE}

The association between residential segregation and workplace segregation weakens but remains statistically significant once we include all the other important control variables into our regression models $1 \mathrm{a}$ and $1 \mathrm{~b}$. This confirms the results of previous studies that the largest part of the association between residential and workplace segregation is actually reflected in variation in other individual characteristics such as education, economic sector where immigrants work, etc., or by the nature of the local labor markets captured by the variable Swedish macro region (Strömgren et al. 2014). The workplace integration of immigrants increases as we move down the urban hierarchy. Compared to those in the Stockholm metropolitan area, immigrant men (women) working in small towns and rural areas, i.e. the rest of Sweden in our models, face a 10\% (17\%) higher share of natives in their workplace. As anti-discriminatory laws are identical across cities and regions, the size of the local immigrant population seems to be related to ethnic niches on the labor market (cf. Hedberg and Tammaru 2013). The year of arrival indicates that each subsequent immigrant cohort works in more segregated workplaces compared to earlier arrivals; e.g., immigrants from the 2000 arrival cohort have about 6-7\% lower native shares in their workplaces compared to their 1990 peers. This confirms previous findings which stress the importance of ongoing immigration for increased segregation levels, both at places of residence and work (Marcinczak et al. 2015). Nevertheless, residential segregation can still explain a significant fraction of workplace segregation within cities, industries, immigrant cohorts and educational groups.

Parks (2004) and Wright et al. (2010) have demonstrated for the USA context, that ethnic labor market niching is highly gendered. Similarly, our analysis with Swedish data show considerable gender differences in workplace segregation across sectors: immigrant women from Global South who work in hotels and restaurants, in wholesale and retail sectors, as well as in public administration are working in the most integrated workplaces. Immigrant men 
from Global South who are working in hotels and restaurants, and low-skilled financial and business services are working in the most integrated workplaces. Surprisingly, both men and women working in high-skilled financial and business services and in education, work in highly segregated workplaces. Whether this result is driven by the low number of Global South immigrants in these sectors, or whether these immigrants offer services specific to other immigrants should be explored in the future.

Next we use fixed effects regression models to find out what are the effects of change in the share of native neighbors on change in the percentage of native co-workers of immigrants during the first five years in Sweden. By doing this, we are able to control for time-invariant unobserved individual characteristics, such as ability or willingness to integrate, that can be important both for settling in ethnic enclaves and niche workplaces. These models also shift the attention towards dynamics in residential segregation and workplace segregation. A drawback of fixed effects models is that all time-invariant factors such as region of origin, immigration cohort or education are dropped from the model automatically. In a study of workplace segregation in Sweden, Strömgren et al. (2014) show that the results from fixed effects models differ markedly from those obtained from modelling structural workplace segregation. Hence, we follow their approach to compare the results from both types of models.

Two important findings emerge from modelling change in workplace segregation (Table 3, Models 2a and 2b). First, there is a significant decrease in the role of residential segregation in workplace segregation compared to models of structural workplace segregation (Table 3, Models 1a and 1b). For men, the estimates from fixed effects regression are only about one ninth of the corresponding estimates from ordinary least squares regression, while the estimates for women drop to one fourth. This means that the largest part of the association between residential and workplace segregation actually is due to the very same underlying individual characteristics such as ability or willingness to integrate into Swedish society that we are not able to measure directly, but which jointly influence both in which residential neighborhoods immigrants live and in which workplaces immigrants work. The regression coefficients drop for native partner as well but less than in case of residential segregation. What is more important, unlike what we found from structural segregation models, the results of the modelling of change reveal significant gender differences in the role of residential segregation in workplace segregation. For women, an increase in the share of natives in residential neighborhoods increases workplace integration, while no such effect can be found for men. For men, unlike for women, intermarriage is important. Getting a Swedish partner is positively related to workplace integration while such an effect cannot be found for women. In other words, the role of neighborhood ethnic context and the role of living with a native partner on workplace integration is highly gendered among immigrants in Sweden from the Global South; women gain from having native neighbors and men gain from having a native partner in moving to more integrated workplaces. These findings confirm previous results based on qualitative data that show that the neighborhood-based social networks of immigrant men are weaker than of women (Hanson and Pratt 1991).

\section{Summary and discussion}

Most previous studies on the relationship between residential segregation and workplace segregation of immigrants take an interest in structural segregation, paying less attention to 
the dynamics of the segregation processes. We focused on the dynamic part by investigating the role of change in residential segregation on change in workplace segregation. We also took into account the effect of intermarriage on workplace segregation, and we investigated the gender dimension of workplace segregation. Most existing quantitative research into workplace segregation pays little attention to gender differences in workplace segregation, which is surprising given the important gender differences in immigrant labor market outcomes (Hedberg and Tammaru 2013; Parks 2004).

Our descriptive findings suggest that even in the Swedish integration-friendly institutional context, residential and workplace integration do not increase with time, at least not during the first years upon arrival of immigrants. We applied a longitudinal research design and we followed 1990, 1995 and 2000 arrival cohorts of Global South immigrants during their first five years in Sweden and we find that both men and women become more residentially segregated during that period. These results diverge from previous findings based on cross-sectional data, which shows decreasing levels of residential segregation for all Global South immigrants in the 2000s, as new immigrants settle both in traditional ethnic enclaves as well as in new destinations (Marcińczak et al. 2015).

There are two possible explanations for the increasing residential segregation of already settled immigrants in Sweden. First, although Sweden is a social democratic welfare regime with generous social and housing benefits, such benefits, especially in the field of housing, have decreased substantially over the past decades (Andersson and Kährik 2015). In other words, the favorable integration context (MIPEX 2015) is not enough for tackling residential segregation of immigrants at times of growing social inequalities. Andersson and Kährik (2015) demonstrate that socio-economic segregation is quickly rising in Sweden, and that there is an overlap between socio-economic and ethnic segregation. Thus, while part of new immigrants settle in new destinations, which has a lowering effect on segregation levels, we still find that the already settled immigrants tend to be stuck in immigrant-dense residential enclaves. We are following the residential context of three immigrant cohorts, and the second possible explanation for their increasing residential segregation hinges on the spatial mobility of other groups. International migration is a network-based phenomenon (Alba and Nee 2003) and as many new immigrants arriving to Sweden find their initial residence also (but not only) in ethnic enclaves (Hedberg and Tammaru 2013), they do boost segregation of already settled migrants too, especially when natives start to leave or avoid such increasingly immigrant-dense residential areas (Andersson and Bråmå 2004; Bråmå 2006).

Workplace segregation of Global South immigrants from natives is higher upon arrival compared to residential segregation, for both men and women. This is most likely caused by a combination of finding jobs through migrant networks and facing difficulties in matching their skills - which were obtained in a very different context - to jobs on the Swedish labor market. Within the first five years in Sweden, workplace segregation of immigrants remains higher compared to residential segregation but, unlike to residential segregation, it starts to reduce with time. Again, the changes are similar for Global South immigrant men and women. We recall that according the MIPEX (2015), Sweden has received the maximum score for labor mobility, and it seems that it does have a positive effect on workplace integration of Global South immigrants with natives. It might be that with time, such favorable changes in work-life start to bring down levels of residential segregation as well. Longitudinal studies that follow immigrant cohorts for even longer periods of time are needed for testing this hypothesis. 
The results of our analysis of structural workplace segregation by means of ordinary least square regression models show that living in neighborhoods with a high share of natives is associated with a higher share of natives in the workplace establishment where immigrants work. This confirms the results obtained from cross-sectional analysis both in USA (Ellis et al. 2004) and Sweden (Marcińczak et al. 2015) that residential and workplace segregation are strongly correlated to each other. Immigrants who live in ethnic enclaves tend to work in ethnic niche sectors, and vice versa. The results from our longitudinal analysis that focused on change in workplace segregation during the five first years in Sweden by means of fixed effects regression models demonstrate, however, that the effect of living in ethnic enclaves on working in ethnic workplaces is not only weaker as expected (cf. Strömgren et al. 2014), but also gendered. In other words, the findings from our longitudinal analysis reveal an important gender dimension in the effect of residential segregation on workplace segregation that remained hidden in the structural analysis. While women do gain from an increasing share of native neighbors in terms of workplace integration, this is not the case for men for whom getting married with a native partner is much more important in facilitating workplace integration. Intriguingly, thus, immigrant men from the Global South do not gain from living in better integrated neighborhoods when it comes to working together with natives. This finding is in line with what has been found in qualitative studies, which show that residential neighborhoods are more important for job related networks of women than for men (Hanson and Pratt 1991).

To conclude, the effects of residential segregation on workplace segregation differ for men and women. We find a positive effect for women; an increase of natives in the residential neighborhood is related to an increase of natives at places of work. This shows that women's social networks are more neighborhood-based and neighbors are more effective in granting them access to 'good jobs' outside ethnic niches. We also observe that immigrant women from the Global South get increasingly intermarried with natives. Although getting intermarried does not have a direct effect on their workplace integration, it contributes to their residential integration which in turn is positively related to workplace integration for women. For men we do not find a significant relationship between an increase of natives in the residential neighborhood and an increase of natives at places of work. This shows that men's social networks are less neighborhood-based and neighbors are less effective in granting them access to 'good jobs' outside ethnic niches. These results confirm that it is important to go beyond residential segregation (Strömgren et al. 2014; van Kempen and Wissink 2014) to understand the integration pathways of immigrants in todays' increasingly ethnically diverse cities. 


\section{References}

Arrow, K. (1973). The theory of discrimination (Industrial Relations Section Working Paper No. 24). Princeton, NJ: Princeton University.

Alba, R. \& Nee, V. (2003). Remaking the American Mainstream. Cambridge, MA: Harvard University Press.

Alba, R., Denton, N., Leung, Shu-yin J., \& Logan, J. R. (1995). Neighborhood change under conditions of mass immigration: The New York city region, 1970-1990. International Migration Review, 29(3), 625-656.

Alonso, W (1964). Location and land use: Towards a general theory of land rent. Cambridge: Harvard University Press.

Andersson, R. \& Bråmå, A. (2004). Selective migration in Swedish distressed neighbourhoods: Can area-based urban policies counteract segregation processes? Housing Studies 19, 517-539.

Andersson, R \& A Kährik 2015, 'Widening gaps: segregation dynamics during two decades of economic and institutional change in Stockholm' in Socio-Economic Segregation in European Capital Cities. East meets West, eds T Tammaru, S Marcińczak, M van Ham \& S Musterd, Routledge, London.

Arbaci, S (2007). Ethnic segregation, housing systems and welfare regimes in Europe' International Journal of Housing Policy 7(4), 401-33.

Arrow, K. (1973). The theory of discrimination (Industrial Relations Section Working Paper No. 24).Princeton, NJ: Princeton University.

Åslund, O. \& Nordström-Skans, O. (2010). Will I see you at work? Ethnic workplace segregation in Sweden, 1985-2002. Industrial and Labor Relations Review, 63(3), 471-493.

Baron, J., \& Bielby, W. (1980). Bringing the firms back in: Stratification, segmentation, and the organization of work. American Sociological Review, 45, 737-765.

Bråmå, Å. (2006). 'White Flight'? The production and reproduction of immigrant concentration areas in Swedish cities, 1990-2000. Urban Studies, 43(7), 1127-1146.

Bygren, M. (2013). Unpacking the causes of ethnic segregation across workplaces. Acta Sociologica, 56(1), 3-19.

Castles, S., de Haas, HJ \& Miller, M. (2013). The Age of Migration. Fifth Edition International Population Movements in the Modern World. Palgrave Macmillan, London.

Damm, A. P. (2014). Neighborhood quality and labor market outcomes: Evidence from quasi-random neighborhood assignment of immigrants. Journal of Urban Economics, 79, 139-166

Dribe M. \& Lundh C. (2008). Intermarriage and immigrant integration in Sweden. Acta Sociologica, 51, 329-354.

Ellis, M., Wright, R., \& Parks, V. (2004). Work together, live apart? Geographies of racial and ethnic segregation at home and at work. Annals of the Association of American Geographers, 94, 620-637.

Ellis, M., Holloway, S. R., Wright, R., \& Fowler, C. S. (2012). Agents of change: Mixed-race households and the dynamics of neighborhood segregation in the United States. Annals of the Association of American Geographers, 102, 549-570.

Feng Z., Boyle P., van Ham M. \& Raab G. (2013). Neighbourhood ethnic mix and the formation of mixed-ethnic unions in Britain: a longitudinal analysis. Geografiska Annaler: Series B, Human Geography, 95(4), 307-321. 
Hanson, S., \& Pratt, G. (1991). Job search and the occupational segregation of women. Annals of the Association of American Geographers, 81, 229-53.

Hanson, S., \& Pratt, G. (1992). Dynamic dependencies: A geographic investigation of local labor markets. Economic Geography, 68, 373-405.

Hanson, Susan, \& Pratt, Geraldine (1988). Reconceptualizing the links between home and work in urban geography. Economic Geography, 64(4), 299-321.

Hedberg, C. \& Tammaru, T. (2013). 'Neighborhood effects' and 'City effects': The entry of newly arrived immigrants into the labor market. Urban Studies, 50(6), 1163-1180.

Hellerstein, J. K., McInerney, M., \& Neumark, D. (2011). Neighbors and coworkers: The importance of residential labor market networks. Journal of Labor Economics, 29(4), 659-695.

Hellerstein, J., \& Neumark, D. (2008). Workplace segregation in the United States: Race, ethnicity, and skill. Review of Economics and Statistics, 90(3), 459-477.

Hou, F. (2009). Immigrants working with co-ethnics: Who are they and how do they fare? International Migration, 47, 69-100.

Kourtit, K., Nijkamp, P., Franklin, R.S., Rodríguez-Pose’ A. (2014). A blueprint for strategic urban research: the urban piazza. Town Planning Review, 85(1), 97-126.

Kwan, M.-P. 2013. (2013). Beyond space (as we knew it): Toward temporally integrated geographies of segregation, health, and accessibility. Annals of the Association of American Geographers, 103(5), 1078-1086.

Logan, J. R., Alba, R. D., \& Zhang, W. Q. (2002). Immigrant enclaves and ethnic communities in New York and Los Angeles. American Sociological Review, 67, 299-322.

Marcinczak, S., Tammaru, T., Strömgren, M. \& Lindgren, U. (2015I. Changing patterns of residential and workplace segregation in the Stockholm metropolitan region. Urban Geography [In press].

MIPEX (2015) Migrant Integration Policy Index. Electroncially available at http://www.mipex.eu/.

Moore, G. (1990). Structural determinants of men's and women's personal networks. American Sociological Review, 55, 726-735.

Musterd, S., Andersson, R., Galster, G. and Kauppinen, T. (2008). Are immigrants' earnings influenced by the characteristics of their neighbors? Environment and Planning A, 40, 785-805.

Niedomysl, T., Östh, J. \& Van Ham, M. (2010). The globalisation of marriage fields: the Swedish case, Journal of Ethnic and Migration Studies, 36, 1119-1138.

Parks, V.A. (2004). The gendered connection between ethnic residential and labor market segregation in Los Angeles. Urban Geography, 25, 589-630.

Rydgren, J. (2004). Mechanisms of exclusion: Ethnic discrimination in the Swedish labor market. Journal of Ethnic and Migration Studies, 30, 697-716.

Schnell, I. \& Yoav, B. (2001). The sociospatial isolation of agents in everyday life spaces as an aspect of segregation. Annals of the Association of American Geographers, 91(4), 622-636.

Silm, S. \& Ahas, R.(2014). Ethnic differences in activity spaces: A study of out-of-home nonemployment activities with mobile phone data. Annals of the Association of American Geographers, 104(3), 542-559.

Strömgren M., Tammaru T., Danzer A.M., van Ham M., Marcinczak S., Stjernström O. \& Lindgren U. (2014). Factors shaping workplace segregation between natives and immigrants. Demography, 51(2), 645-671. 
Syrett, S \& Sepulveda, L. (2012). Urban governance and economic development in the diverse city. European Urban and Regional Studies, 19(3), 238-253.

Tammaru, T., Strömgren, M., Stjernström, O. \& Lindgren, U. (2010). Learning through contact? The effects on earnings of immigrant exposure to the native population. Environment and Planning A, 42, 2938-2955.

Tammaru, T., Musterd, S., van Ham, M. \& Marcińczak, S. (2015). A multi-factor approach to understanding socio-economic segregation in European capital cities, in Socio-Economic Segregation in European Capital Cities. East meets West, eds T Tammaru, S Marcińczak, M van Ham \& S Musterd, Routledge, London.

Tomaskovic-Devey, D., Stainback, K., Taylor, T., Zimmer, C., Robinson, C., \& McTague, T. (2006). Documenting desegregation: Segregation in American workplaces by race, ethnicity, and sex, 1966-2003. American Sociological Review, 71(4), 565-588.

van Ham, M., Hooimeijer, P. \& Mulder, C. (2001). Urban form and job access: Disparate realities in the Randstad. Journal of Economic and Social Geography, 92, 231-246.

Wissink, B., R. van Kempen, Y. Fang \& S.M. Li (2012). Introduction: Living in Chinese enclave cities', Urban Geography, 33(2), 161-166.

Wong, D.W.S. \& Shaw, S.L. (2011) 'Measuring segregation: an activity space approach', Journal of Geographical Systems, 13(2), 127-145.

Wright, R., Ellis, M. \& Parks, V. (2010). Immigrant niches and the intrametropolitan spatial division of labor. Journal of Ethnic and Migration Studies, 36, 1033-1059. 
Table 1. Characteristics of the research population.

\begin{tabular}{|c|c|c|c|c|c|}
\hline & & & Total & Males & Females \\
\hline \multicolumn{6}{|l|}{ Exposure } \\
\hline $\begin{array}{l}\text { Neighbourhood } \\
\text { exposure }\end{array}$ & (continuous; \%) & Mean & 75 & 73 & 77 \\
\hline Partnership & No partner [ref] & & 43 & 47 & 37 \\
\hline \multirow[t]{2}{*}{ status } & Native partner & & 16 & 12 & 22 \\
\hline & Foreign-born partner & & 41 & 41 & 41 \\
\hline $\begin{array}{l}\text { Neighbourhood } \\
\text { population size }\end{array}$ & (continuous; no. of inhabitants) & Mean & 4057 & 4225 & 3836 \\
\hline \multirow[t]{5}{*}{ Macro region } & Stockholm [ref] & & 50 & 51 & 48 \\
\hline & Gothenburg & & 12 & 12 & 14 \\
\hline & Malmö & & 8 & 7 & 8 \\
\hline & Large regional centres & & 23 & 23 & 22 \\
\hline & Rest of Sweden & & 7 & 7 & 8 \\
\hline Age & (continuous; years) & Mean & 29 & 29 & 29 \\
\hline \multirow[t]{3}{*}{ Education } & Compulsory [ref] & & 35 & 35 & 36 \\
\hline & Secondary & & 29 & 29 & 28 \\
\hline & University & & 36 & 36 & 36 \\
\hline \multirow[t]{3}{*}{ Year of arrival } & 1990 [ref] & & 42 & 45 & 38 \\
\hline & 1995 & & 22 & 20 & 24 \\
\hline & 2000 & & 36 & 35 & 38 \\
\hline \multirow{4}{*}{$\begin{array}{l}\text { Region of } \\
\text { origin }\end{array}$} & Middle East [ref] & & 33 & 40 & 23 \\
\hline & Asia & & 33 & 25 & 43 \\
\hline & Africa & & 16 & 18 & 15 \\
\hline & South America & & 18 & 17 & 19 \\
\hline \multirow[t]{2}{*}{ Swedish citizen } & Yes & & 7 & 7 & 8 \\
\hline & No [ref] & & 93 & 93 & 92 \\
\hline \multirow[t]{10}{*}{ Industry } & Manufacturing [ref] & & 20 & 24 & 14 \\
\hline & Wholesale and retail & & 6 & 7 & 5 \\
\hline & Hotels and restaurants & & 17 & 18 & 17 \\
\hline & Transport and communication & & 5 & 6 & 3 \\
\hline & Fin. and business services (low- & killed) & 14 & 13 & 15 \\
\hline & Fin. and business services (high & killed) & 5 & 6 & 5 \\
\hline & Public administration & & 2 & 2 & 2 \\
\hline & Education & & 9 & 8 & 11 \\
\hline & Health, social and other service & & 21 & 15 & 27 \\
\hline & Undefined & & 1 & 1 & 1 \\
\hline
\end{tabular}


Table 2. Share of natives at places of work and residence of immigrant, and share of immigrants intermarried with natives at arrival and 5 years since arrival.

\begin{tabular}{ccccc}
\hline & \multicolumn{2}{c}{ Males } & \multicolumn{2}{c}{ Females } \\
\cline { 2 - 4 } & Year 1 & Year 5 & Year 1 & Year 5 \\
Mean & Mean & Mean & Mean \\
\hline
\end{tabular}

Workplace exposure

Middle East

$\begin{array}{llll}64 & 66 & 66 & 70 \\ 59 & 64 & 64 & 66 \\ 66 & 65 & 63 & 66 \\ 64 & 67 & 67 & 72\end{array}$

Asia

Africa

South America

$\begin{array}{llll}75 & 71 & 75 & 72 \\ 74 & 72 & 80 & 79 \\ 75 & 68 & 73 & 70 \\ 79 & 75 & 79 & 78\end{array}$

Native partner

Middle East

\begin{tabular}{cccc}
13 & 7 & 5 & 3 \\
18 & 12 & 32 & 38 \\
19 & 10 & 13 & 12 \\
15 & 14 & 20 & 23 \\
\hline
\end{tabular}


Table 3. Ordinary least squares (OLS) and fixed-effects (FE) regression estimates of workplace segregation for male and female immigrants.

\begin{tabular}{|c|c|c|c|c|c|c|c|c|c|}
\hline \multirow{3}{*}{$\begin{array}{l}\text { Neighbourhood exposure } \\
\end{array}$} & \multirow[b]{3}{*}{ (continuous; \%) } & \multicolumn{4}{|c|}{ Males } & \multicolumn{4}{|c|}{ Females } \\
\hline & & \multicolumn{2}{|c|}{$\begin{array}{l}\text { OLS } \\
\text { Model 1a }\end{array}$} & \multicolumn{2}{|c|}{$\begin{array}{c}\mathrm{FE} \\
\text { Model 2a }\end{array}$} & \multicolumn{2}{|c|}{$\begin{array}{c}\text { OLS } \\
\text { Model } 1 \mathrm{~b}\end{array}$} & \multicolumn{2}{|c|}{$\begin{array}{c}\mathrm{FE} \\
\text { Model } 2 \mathrm{~b}\end{array}$} \\
\hline & & $0.416^{* * *}$ & $\frac{1 \mathrm{a}}{0.171^{* * *}}$ & $\frac{\text { Mlode }}{0.055^{* * *}}$ & 0,02 & $\frac{\text { Mode }}{0.411^{* * *}}$ & $1 \mathrm{~b}$ & $0.080^{* * *}$ & $0.047^{* *}$ \\
\hline & & 0,023 & 0,016 & 0,015 & 0,015 & 0,024 & 0,018 & 0,022 & 0,021 \\
\hline \multirow{4}{*}{$\begin{array}{l}\text { Partnership status } \\
\text { (Ref.: No partner) }\end{array}$} & Native partner & 1,235 & $3.424^{* * *}$ & $1.855^{* *}$ & $1.548^{* *}$ & $1.278^{* *}$ & $3.502^{* * *}$ & 0,153 & 0,312 \\
\hline & & 0,766 & 0,582 & 0,819 & 0,751 & 0,638 & 0,553 & 0,723 & 0,667 \\
\hline & Foreign-born partner & $-0,092$ & $-1.448^{* * *}$ & $-0,316$ & 0,075 & $-0,27$ & $-2.593^{* * *}$ & $-1,163$ & $-0,573$ \\
\hline & & 0,519 & 0,445 & 0,485 & 0,431 & 0,562 & 0,469 & 0,724 & 0,635 \\
\hline \multirow{8}{*}{$\begin{array}{l}\text { Year since arrival } \\
\text { (Ref.: Year 1) }\end{array}$} & Year 2 & $1.249^{* * *}$ & $0.783^{* *}$ & $0.746^{* * *}$ & $0.583^{* *}$ & $1.091^{* *}$ & $0.638^{*}$ & $0.766^{* *}$ & $0.583^{* *}$ \\
\hline & & 0,406 & 0,372 & 0,282 & 0,269 & 0,444 & 0,378 & 0,304 & 0,285 \\
\hline & Year 3 & $1.363^{* * *}$ & $0.811^{*}$ & $1.058^{* * *}$ & $0.719^{* *}$ & $2.194^{* * *}$ & $0.909 * *$ & $1.336^{* * *}$ & $0.802^{* *}$ \\
\hline & & 0,493 & 0,435 & 0,343 & 0,329 & 0,518 & 0,429 & 0,377 & 0,351 \\
\hline & Year 4 & $2.972^{* * *}$ & $0.830^{*}$ & $1.184^{* * *}$ & $0.649 * *$ & $3.026^{* * *}$ & 0,733 & $1.385^{* * *}$ & $0.680^{*}$ \\
\hline & & 0,508 & 0,481 & 0,33 & 0,318 & 0,556 & 0,477 & 0,414 & 0,385 \\
\hline & Year 5 & $3.912^{* * *}$ & $1.367^{* * *}$ & $1.047 * * *$ & 0,492 & $3.953^{* * *}$ & 0,677 & $1.590^{* * *}$ & 0,412 \\
\hline & & 0,517 & 0,489 & 0,36 & 0,362 & 0,568 & 0,507 & 0,443 & 0,446 \\
\hline Neighbourhood populatior & (continuous; no. of inhabitants) & & $-0.000142^{* *}$ & & $-0,0000675$ & & $0.000191^{* * *}$ & & 0,0000158 \\
\hline & & & 0,000064 & & 0,0000593 & & 0,0000694 & & 0,0000831 \\
\hline Macro region & Gothenburg & & $6.096 * * *$ & & 1,985 & & $9.326^{* * *}$ & & $4.569^{* *}$ \\
\hline (Ref.: Stockholm) & & & 0,797 & & 1,514 & & 0,723 & & 2,089 \\
\hline & Malmö & & $5.801^{* * *}$ & & 1,396 & & $8.424^{* * *}$ & & $-0,374$ \\
\hline & & & 0,911 & & 1,697 & & 0,875 & & 3,229 \\
\hline & Large regional centres & & $9.030^{* * *}$ & & $4.071^{* * *}$ & & $13.281 * * *$ & & $6.404^{* * *}$ \\
\hline & & & 0,712 & & 1,072 & & 0,672 & & 1,679 \\
\hline & Rest of Sweden & & $10.452^{* * *}$ & & $5.730^{* * *}$ & & $17.102^{* * *}$ & & $9.895^{* * *}$ \\
\hline & & & 1,017 & & 1,496 & & 0,809 & & 1,962 \\
\hline Age at arrival & (continuous; years) & & $-0,04$ & & & & $-0,034$ & & \\
\hline & & & 0,034 & & & & 0,033 & & \\
\hline Education & Secondary & & $3.752^{* * *}$ & & & & $1.722^{* * *}$ & & \\
\hline (Ref.: Compulsory) & & & 0,489 & & & & 0,565 & & \\
\hline & University & & $5.994^{* * *}$ & & & & $3.056^{* * *}$ & & \\
\hline & & & 0,529 & & & & 0,564 & & \\
\hline Year of arrival & 1995 & & $-3.425^{* * *}$ & & & & $-4.566 * * *$ & & \\
\hline (Ref.: 1990) & & & 0,571 & & & & 0,58 & & \\
\hline & 2000 & & $-7.319^{* * *}$ & & & & $-7.403^{* * *}$ & & \\
\hline & & & 0,517 & & & & 0,528 & & \\
\hline Region of origin & Asia & & $-2.197^{* * *}$ & & & & $-1.891^{* * *}$ & & \\
\hline (Ref.: Middle East) & & & 0,663 & & & & 0,607 & & \\
\hline & Africa & & $2.419^{* * *}$ & & & & $1.205^{*}$ & & \\
\hline & & & 0,589 & & & & 0,619 & & \\
\hline & South America & & $3.776^{* * *}$ & & & & $1.013^{*}$ & & \\
\hline & & & 0,509 & & & & 0,611 & & \\
\hline Swedish citizen & Yes & & $-0,719$ & & $-0,722$ & & $1.732^{* * *}$ & & 0,568 \\
\hline (Ref.: No) & & & 0,712 & & 0,539 & & 0,625 & & 0,55 \\
\hline Industry & Wholesale and retail & & $-2.697^{* *}$ & & $-0,56$ & & $2.338^{*}$ & & $-0,153$ \\
\hline (Ref.: Manufacturing) & & & 1,128 & & 1,513 & & 1,398 & & 1,874 \\
\hline & Hotels and restaurants & & $-17.717^{* * *}$ & & $-8.586 * * *$ & & $-11.023 * * *$ & & $-2.568^{*}$ \\
\hline & & & 0,818 & & 1,178 & & 0,88 & & 1,436 \\
\hline & Transport and communication & & 0,604 & & 0,93 & & $4.707^{* * *}$ & & $8.423^{* * *}$ \\
\hline & & & 0,845 & & 1,204 & & 1,578 & & 2,163 \\
\hline & Financial and business services (lo & w-skilled) & $-27.358^{* * *}$ & & $-23.531^{* * *}$ & & $-21.476^{* * *}$ & & $-17.269 * * *$ \\
\hline & & & 0,824 & & 1,255 & & 0,94 & & 1,457 \\
\hline & Financial and business services ( $h$ & igh-skilled) & $2.239^{* *}$ & & $-2.649^{* *}$ & & $6.730^{* * *}$ & & $3.660^{* *}$ \\
\hline & & & 1,081 & & 1,291 & & 1,24 & & 1,716 \\
\hline & Public administration & & $-0,752$ & & $-3,035$ & & 1,9 & & $6.408^{* * *}$ \\
\hline & & & 1,225 & & 1,887 & & 1,722 & & 2,111 \\
\hline & Education & & $7.780^{* * *}$ & & $6.543^{* * *}$ & & $8.155^{* * *}$ & & $10.147^{* * *}$ \\
\hline & & & 0,674 & & 1,239 & & 0,775 & & 1,442 \\
\hline & Health, social and other services & & $3.405^{* * *}$ & & $2.914^{* *}$ & & $5.109^{* * *}$ & & $6.782^{* * *}$ \\
\hline & & & 0,699 & & 1,18 & & 0,65 & & 1,227 \\
\hline & Undefined & & $-3,278$ & & $-0,018$ & & $-1,613$ & & 1,952 \\
\hline & & & 2,264 & & 2,401 & & 2,59 & & 2,898 \\
\hline & Constant & $31.596 * * *$ & $53.981^{* * *}$ & $59.002^{* * *}$ & $64.293^{* * *}$ & $32.834^{* * *}$ & $54.331 * * *$ & $59.816^{* * *}$ & $59.153^{* * *}$ \\
\hline & & 1,982 & 1,836 & 1,134 & 1,523 & 2,141 & 2,077 & 1,733 & 2,17 \\
\hline Observations & & 25008 & 25008 & 25008 & 25008 & 18985 & 18985 & 18985 & 18985 \\
\hline R-squared & & 0,076 & 0,336 & 0,003 & 0,138 & 0,083 & 0,366 & 0,004 & 0,154 \\
\hline Number of pid & & & & 7474 & 7474 & & & 5805 & 5805 \\
\hline Robust standard errors in $p$ & entheses & & & & & & & & \\
\hline${ }^{* * *} \mathrm{p}<0.01,{ }^{* *} \mathrm{p}<0.05, * \mathrm{p}<0$ & & & & & & & & & \\
\hline
\end{tabular}

